again represented mineralogically by the formation of albite and probably other soda-bearing felspars.

The transfer has been disputed by some observers, but the evidence is too strong to be denied, even if it may be proved that there are exceptions. It has also been suggested that the transfer has not taken place at the time of intrusion,- - that it is not a contactphenomenon at all,- but is due to later processes connected with the decay of the igneous rock. This is a point still calling for investigation.

I hope later on to deal with the subject of these basic contacts, as $I$ am at present engaged in examining a large series of such rocks.

All that I need here remark is that I have fully satisfied myself of the transfer of soda, and of the presence in some cases of large amounts of isotropic material due to contact-action.

\title{
IV.-Note on a Tooth of Oxyrhina from the Red Crag of
} SUFFOLK.

By Arthur Smith Woodward, F.L.S., F.G.S.

A LL the Selachian teeth hitherto obtained from the English A Crags referable to the genus Oxyrhina are much compressed antero-posteriorly, and are thus slender in proportion to their size. They are now commonly regarded as representing a single extinct species, Oxyrhina hastalis of Agassiz, ' and the same form of dentition

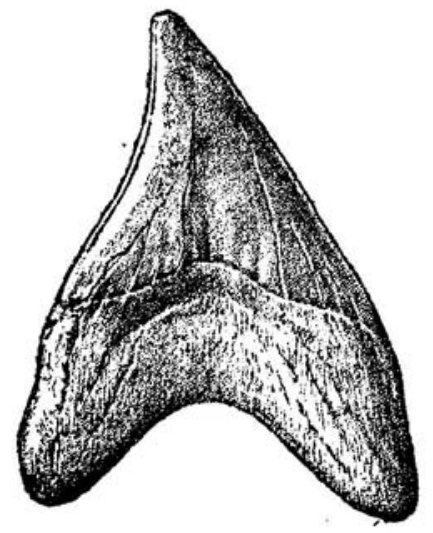

A

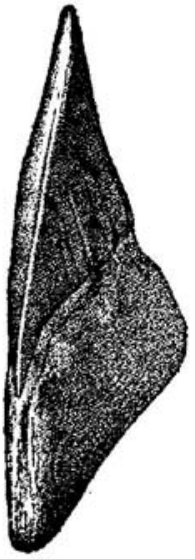

B

Tooth of Oxyrhina crassa, Ag., natural size, from the external (A) and lateral

(B) aspects; Red Crag, Hemley Hall, near Woodbridge, Suffolk.

[Collection of T. W. Reader, Esq., F.G.S.]

is abundant in the Pliocene of Italy. besides occurring in other Tertiary deposits in various parts of the world. In Italy and Belgium, however, these comparatively slender teeth are accompanied by a few

1 Smith Woodward, "Catal. Foss. Fishes, B. M.," pt. i. p. 385; E. T. Newton, "Verteb. Pliocene Dep. Britain" (Hem. Geol. Surv. 1891), p. 106, pl. ix. tig. 10. 
others of the same genus of very robust proportions; and some of these have received the names of $O$. Benedeni, ${ }^{1} O$. gibbosissima, and $O$. Forestii, ${ }^{2}$ while others have been identified with $O$. crassa and O. quadrans. ${ }^{3}$ So far as the present writer can judge, none of these robust teeth are capable of being satisfactorily distinguisbed from the species $O$. crassa of Agassiz, originally described from the Miocene of the Rbine Valley $;^{4}$ and it is under the last-mentioned name that they are recorded in the British Museum Catalogue.

It is now of interest to announce that the same form of robust tooth has lately been obtained from the English Pliocene. The specimen was discovered by Mr. T. W. Reader, F.G.S., in the Red Crag of Hemley Hall, near Woodbridge, and it is shown of the natural size from the external and lateral aspects in the accompanying figures. As indicated by its shape, the tooth must have occupied a postero-lateral position in the mouth, probably in the upper jaw ; and a specimen most closely approaching it is described by Lawley from the Pliocene of Italy under the name of Oxyrhina quadrans. ${ }^{5}$

In general aspect, of course, the new fossil is at first sight suggestive of a tooth of the so-called Otodus obliquus, wanting the lateral denticles. The specimen, however, is quite unabraded and has not the appearance of a derived fossil; while it is certain that the absence of denticles is not the result of fracture. It may be that some such robust teeth are abnormal examples from the dentition of Otodus obliquus; but, in default of all proof of this possibility, it seems advisable to retain the nomenclature here adopted.

\section{V.-An Ancinet Glactal Shore.}

By T. Mellard Reade, C.E., F.G.S., F.R.I.B.A.

$\mathrm{T}^{\mathrm{N}}$ a cutting of the Seacombe Branch of the Wirral Railway at the present moment is to be seen a deposit which cannot be other then a glacial shore. ${ }^{6}$ It is about 18 inches thick, covered by a bed of Boulder-clay some 8 feet thick, and has been exposed by the cutting for a distance of 16 chains running south-east and north-west, to the south-east of the point of intersection of the Railway with Poulton Road. The rise is 16 feet in this distance at a regular up-grade towards Poulton Road, and the average level about 60 feet above O.D. Transversely to the Railway it is about level, and over the whole of the area--1056 feet by 30 feet $=3520$ superficial yards-the deposit occurred and was excavated by the steam navvy. The bed is composed of pretty clean sand with some small gravel, and is crowded with shell fragments in all stages of decay. It is precisely like a modern beach in constitution, extent and slope, but what renders the fact more certain is the

1 H. Le Hon, "Prélim. Mém. Poiss. Tert. Belg." (1871), p. 6, with figure.

2 R. Lawley, "Nuovi Studi Pesci, etc., Colline Toscane" (1876), p. 31.

3 R. Lawley, ibid. and "Studi Comp. Pesci foss. coi viv. generi Carcharodon Oxyrhina, e Galeocerdo" (1881), p. 112, pl. iv. (Oxyrhina), fig. 2.

4 L. Agassiz, " Rech. Poiss. Foss." vol. iii. (1843), p. 283, pl. xxxvii. fig. 16.

5 Op. eit. 1881, pl. iv. (Oxyrhina), fig. 2.

${ }^{6} \mathrm{I}$ am indebted to Mr. Henry Beasley, the Hon. Sec. of the Liverpool Geological Society, for calling my attention to this interesting bed. 